Article

\title{
Reduced Diversity in the Bacteriome of the Phytophagous Mite Brevipalpus yothersi (Acari: Tenuipalpidae)
}

\author{
Oscar E. Ospina ${ }^{1}$, Steven E. Massey ${ }^{2}$ and Jose Carlos Verle Rodrigues ${ }^{1, *}$ \\ 1 Center for Excellence in Quarantine and Invasive Species, Agricultural Experimental Station-Río Piedras, \\ Crops and Agro-Environmental Sciences Department, University of Puerto Rico-Mayaguez, \\ 1193 Calle Guayacán, San Juan, PR 00926-1118, USA; ospina.oe@gmail.com \\ 2 Bioinformatics Laboratory, Department of Biology, University of Puerto Rico-Río Piedras, San Juan, \\ PR 00931-3360, USA; stevenemassey@gmail.com \\ * Correspondence: jose_carlos@mac.com; Tel.: +1-787-767-9705; Fax: +1-787-756-8329
}

Academic Editors: Eric W. Riddick and Andrew G. S. Cuthbertson

Received: 27 September 2016; Accepted: 12 December 2016; Published: 20 December 2016

\begin{abstract}
Tenuipalpidae comprises mites that transmit viruses to agriculturally important plants. Several tenuipalpid species present parthenogenesis, and in Brevipalpus yothersi, the endosymbiont Cardinium has been associated with female-only colonies. It is unclear what the bacterial composition of $B$. yothersi is, and how common Cardinium is in those microbiomes. We performed a comparative analysis of the bacteriomes in three populations of B. yothersi and three additional Tetranychoidea species using sequences from V4-fragment of 16S DNA. The bacteriomes were dominated by Bacteroidetes (especially Cardinium) and Proteobacteria, showing a remarkably low alpha diversity. Cardinium was present in about $22 \%$ of all sequences; however, it was not present in $R$. indica and T. evansi. In B. yothersi, the proportion of Cardinium was higher in adults than eggs, suggesting that proliferation of the bacteria could be the result of selective pressures from the host. This hypothesis was further supported because colonies of $B$. yothersi from different populations showed different bacterial assemblages, and bacteriomes from different mite species showed similar abundances of Cardinium. A phylogenetic analysis of Cardinium revealed that not only specialization but horizontal transmission has been important for this symbiosis. Together, these results represent a glimpse into the evolution of the Tetranychoidea and Cardinium.
\end{abstract}

Keywords: bacterial diversity; Brevipalpus yothersi; false spider mite; Cardinium; habitat filtering; $16 \mathrm{~S}$ ribosomal RNA; Tetranychoidea; Raoiella indica; Tetranychus evansi; Oligonychus

\section{Introduction}

The mite family Tenuipalpidae has gained prominence in the last two decades as an emerging pest for agricultural and ornamental crops such as citrus, coffee, passion vine, tea, pistachio, and palms [1-3]. Particularly, the genus Brevipalpus has emerged as a major pest because of its capacity to transmit virus to crop plants. The most prolific vector species that has been reported is Brevipalpus phoenicis Geijskes, for which recent studies indicated that the species has been perpetually misidentified, and that it is actually $B$. yothersi Baker [4,5]. This species was reported to transmit viruses associated with two major cytopathology groups [6] and belonging to at least two virus families [7]. Interestingly, these mites reproduce by asexual thelytoky associated with the "feminizing" endosymbiont Cardinium [8,9].

Studies have shown that the presence of endosymbiotic bacteria has the potential to manipulate traits such as nutrition [10,11], immune response [12,13], and reproduction [14,15] in arthropods. In fact, it has been proposed that bacterial symbionts have driven to a large degree the evolution of many 
arthropod taxa by increasing fitness, adaptation, and specialization to different environments [16-18]. Such a close relationship between host and endosymbiont is probably the result of both ecological interactions among symbionts and selective pressures posed by the host [19]. Although literature regarding host-symbiont interactions is extensive, less attention has been directed to the study of these interactions under different conditions imposed by different plant hosts.

The ecological conditions of an arthropod host change along different life stages, which also may alter the conditions in the microhabitat of endosymbionts. It has been reported that bacterial communities in larvae of the mosquito Anopheles gambiae were different from those in adults: Adult A. gambiae showed a decrease in bacterial diversity in comparison to their larvae and there was a drastic shift from a species-rich community to an Enterobacteraceae-dominated bacteriome [20]. Conversely, the bacterial assemblage of the beetle Agrilus planipennis was significantly more species-rich in the pre-pupae than in both larval and adult stages [21]. In both cases, a specialization in metabolic function of the bacteriome has been suggested as the consequence (or cause) of these changes. Although ontogenic development in insects is different to that in mites, specialization in bacterial diversity is also expected in mites due to equally significant morphological and physiological changes from eggs to adults.

Specialization of the microbiome has also had effects on processes such as reproduction. For example, Wolbachia and Cardinium endosymbionts distort sex ratios and affect fitness and survival in a wide variety of arthropods and other invertebrates $[8,9,14,16,22,23]$. In fact, it has been shown that elimination of Cardinium results in decreasing survival and reproductive fitness in insects [24]. If the same situation holds true for $B$. yothersi, it is expected that the vertically-transmitted Cardinium will maintain or increase its abundance at different life stages of the host. To the best of our knowledge, no deep assessment of this kind has been performed for the bacterial communities and abundance of Cardinium in B. yothersi.

We made an assessment of the bacterial communities in populations of $B$. yothersi obtained from different plant hosts and at different life stages. Understanding the microbiota associated to this species will enhance our knowledge about the evolution of its asexuality, and further develop strategies for its management. Specifically, we defined the composition and abundance of different bacterial groups and tested for changes in abundance of the endosymbiont Cardinium between mite populations and their adult and egg stages.

\section{Materials and Methods}

\subsection{Collection, Identification, and Laboratory Rearing of Mite Species}

Specimens of Brevipalpus mites were initially identified as B. phoenicis, but are now recognized as $B$. yothersi Baker [5]. Those specimens were originally collected from three different hosts in Puerto Rico: Sweet orange (Citrus sinensis, Rutaceae), Tahiti lime (Citrus latifolia, Rutaceae), and glory-bower (Clerodendrum thomsoniae, Lamiaceae). Mite colonies were established by a single egg and maintained in fruit-arenas of "Valencia" sweet orange for 10 generations in an environmental chamber (Precision Model 818; Thermo Scientific, Waltham, MA, USA) at $25{ }^{\circ} \mathrm{C}$ and $75 \%$ relative humidity [25]. As outgroups, all in the Tetranychoidea superfamily, we included samples of adult Tetranychus evansi obtained from tomato plants (Solanum lycopersicum, Solanaceae) in the field, as well as colonies of Raoiella indica from coconut (Cocos nucifera, Arecaceae), and an Oligonychus mite (from dry beans, Phaseolus vulgaris, Fabaceae) collected at the Rio Piedras Agricultural Station. For identification, specimens from all species were slide-mounted in Hoyer's medium and barcoded using previously described primers for the mitochondrial Cytochrome Oxidase Subunit I gene (COI) [25]. Accession numbers for the mites used in this study were deposited at GenBank (Accession numbers: KP180424 to KP180429). 


\subsection{Genomic DNA Extraction and Pyrosequencing}

We extracted total genomic DNA from 20 eggs and 20 mites per colony following the CTAB (Cetyl Trimethyl-Ammonium Bromide) method used in previous studies [25,26]. The DNA extraction manipulations were conducted in a clean laminar flow chamber and we used certified DNA-free tubes and reagents. The mites were washed in $0.05 \%$ hypochlorite bleach and rinsed thoroughly with DNA-free water before DNA extraction. We used the primers bac515F (5'-GTGCCAAGCMGCCGCGGTAA-3') and bac806R (5'-GTGCCAAGCMGCCGCGGTAA-3') to amplify $\approx 250 \mathrm{bp}$ of the V4 region coding for part of the $16 \mathrm{~S}$ Ribosomal Subunit (16S) with the HotStarTaq Plus Master Mix Kit (Qiagen, Hilden, Germany). PCR conditions included an initial stage of $3 \mathrm{~min}$ at $94{ }^{\circ} \mathrm{C}$, followed by 28 cycles of $94{ }^{\circ} \mathrm{C}$ for $30 \mathrm{~s}, 53{ }^{\circ} \mathrm{C}$ for $40 \mathrm{~s}$, and $72{ }^{\circ} \mathrm{C}$ for $1 \mathrm{~min}$. The final elongation step was performed at $72{ }^{\circ} \mathrm{C}$ for $5 \mathrm{~min}$. Negative control samples (no mites) were included and processed equally during all steps in order to detect eventual bacterial contamination.

A construct composed by the primers previously mentioned, a linker sequence, and a sample-specific oligonucleotide tag (a.k.a barcode) was incorporated for sequencing on a 454 GS FLX System (Roche, Branford, CT, USA) (Table 1). The inclusion of this linker into the amplicons was made with a second PCR using $1 \mu \mathrm{L}$ of the previous PCR product under the same conditions. A purification of these PCR products was done with the Agencourt Ampure Beads (Agencourt Bioscience, La Jolla, CA, USA). An estimation of the size and concentration of the amplicons was made by using DNA chips and the Bio-Rad Experion Automated Electrophoresis Station (Bio-Rad, Hercules, CA, USA). The FLX sequencing solution contained $9.6 \times 10^{6}$ DNA molecules $/ \mu \mathrm{L}$ mixed with 6 million binding beads. This DNA-bead solution was amplified by using emulsion PCR [27] and then, DNA on the binding beads was denatured with $\mathrm{NaOH}$. An FLX sequencing run was performed using a Genome Sequencer FLX System (Roche) on a $70 \times 75$ GS Picotiter Plate (PTP) by following instructions from the manufacturer.

Table 1. Specific tags used to identify each of the samples after multiplexed FLX sequencing.

\begin{tabular}{cccc}
\hline Species & Host Plant & Stage & Tag \\
\hline \multirow{3}{*}{ Brevipalpus yothersi } & Glory-bower & $\begin{array}{c}\text { eggs } \\
\text { adults }\end{array}$ & $\begin{array}{c}\text { GAGATCAG } \\
\text { GAGTAGAC }\end{array}$ \\
\cline { 2 - 4 } & Sweet orange & $\begin{array}{c}\text { eggs } \\
\text { adults }\end{array}$ & $\begin{array}{c}\text { GAGATCTC } \\
\text { GAGATGAC }\end{array}$ \\
\cline { 2 - 4 } & Tahiti lime & $\begin{array}{c}\text { eggs } \\
\text { adults }\end{array}$ & $\begin{array}{c}\text { GAGTACTC } \\
\text { GAGTACAG }\end{array}$ \\
\hline \multirow{2}{*}{ Raoiella indica } & Coconut & $\begin{array}{c}\text { eggs } \\
\text { adults }\end{array}$ & GAGTCACT \\
\hline Oligonychus sp. & Bean & $\begin{array}{c}\text { eggs } \\
\text { adults }\end{array}$ & GATGAGCA \\
\hline Tetranychus evansi & Tomato & adults & GAGTAGAGG \\
\hline
\end{tabular}

\subsection{Data Processing and Quality Control}

We performed an initial processing and filtering of the sequence reads by using a pipeline of scripts included in the MacQIIME 1.8.0 distribution [28]. Sequence (.fasta) and quality (.qual) files were obtained from the flowgram file (.sff) generated by the FLX platform using QIIME's "process_sff.py" script. During the de-multiplexing, we also eliminated the primer, linkers, and barcodes from the reads. Sequences with average Quality Score lower than 25 were discarded from subsequent analysis. This new set of filtered sequences was denoised and aligned in PyNAST v1.2 against the Greengenes reference alignment [29]. Sequences with less than $30 \%$ in similarity to the reference alignment where excluded from subsequent analysis. Identification and elimination of chimeric sequences was performed with ChimeraSlayer v4.29.2010 as implemented in MacQIIME and using the template alignment provided by PyNAST. 


\subsection{Analysis of Bacterial Diversity}

We assigned the taxonomy and produced estimations diversity with the pipeline implemented in MacQIIME. Following, we present some of the key points of this pipeline. We made clusters based on a 97\% of similarity and identified Operational taxonomic units (OTUs) in the quality-filtered dataset. Each OTU was assigned taxonomy by using the Ribosomal Database Project (RDP) Classifier v2.11 [30] and singletons were discarded from subsequent analyses.

To estimate diversity inside each sample (i.e., alpha diversity) we rarefied the sequences 10 times adding 50 sequences by rarefaction. Averages for the Chao1 and Shannon indexes were calculated based on such rarefactions. Based on the rarefied dataset, we also estimated the unweighted and weighted UniFrac distances, and the Bray-Curtis dissimilarity index. With these estimators, a Principal Coordinate Analysis (PCoA) was performed.

\subsection{Phylogenetic Analysis of Cardinium Strains}

We extracted from the entire dataset the OTUs assigned as Cardinium by the RDP Classifier. Additionally, we obtained representative sequences from all the Cardinium available at GenBank regardless of the host where it was isolated. Maximum Parsimony trees were created using the algorithm included in MEGA v6 [31]. The resulting consensus tree was resampled 1000 times by bootstrapping and branches with less than $50 \%$ in support were collapsed.

\section{Results}

\subsection{Composition of the Bacteriomes}

Sequences were deposited in GenBank Bioproject PRJNA354805. This is the first assessment of the bacterial communities in Brevipalpus and other Tetranychoidea. Our results show that the bacterial communities of those Tetranychoidea were dominated by Bacteroidetes and Proteobacteria. Other groups present in lesser proportions were Actinobacteria, and Firmicutes (Figure 1). Among these, we found OTUs assigned to known bacterial endosymbionts belonging to the genera Cardinium (OTUs 33, 190, 233, 314, 335, 445, 455, 457, 460, 547, 625, 805, 843, 888), Portiera (OTU 863), Tremblaya (OTU 516), and Wolbachia (OTU 1043). The most abundant of the endosymbionts was Cardinium, being present in about $22 \%$ of all sequences; however, it was not present in $R$. indica or T. evansi (Table 2). Representative 16S sequences for Cardinium and the other endosymbionts are deposited at GenBank (Accession numbers: KX844704 to KX844707). A table with the OTUs for the bacterial taxa found in these mites and their identification numbers is provided as Supplementary Materials (Table S1).

Table 2. Percentage of sequences per sample classified as mite endosymbionts (according to [32-34]).

\begin{tabular}{|c|c|c|c|c|c|c|}
\hline Mite Species & Host & Stage & Cardinium & Portiera & Tremblaya & Wolbachia \\
\hline \multirow{6}{*}{ Brevipalpus yothersi } & \multirow{2}{*}{ Glory-bower } & Eggs & 7.9 & - & - & - \\
\hline & & Adults & 71.5 & - & - & - \\
\hline & \multirow{2}{*}{ Sweet orange } & Eggs & 11.1 & - & - & 0.1 \\
\hline & & Adults & 26.5 & - & - & - \\
\hline & \multirow{2}{*}{ Tahiti lime } & Eggs & 6.4 & 0.3 & - & - \\
\hline & & Adults & 22.2 & - & - & - \\
\hline \multirow{2}{*}{ Raoiella indica } & \multirow{2}{*}{ Coconut } & Eggs & - & - & - & - \\
\hline & & Adults & - & - & $<0.1$ & - \\
\hline \multirow{2}{*}{ Oligonychus sp. } & \multirow{2}{*}{ Bean } & Eggs & 12.6 & - & - & - \\
\hline & & Adults & 90.9 & - & - & - \\
\hline Tetranychus evansi & Tomato & Adults & - & - & - & - \\
\hline \multicolumn{3}{|c|}{ All the sequences } & 22.25 & 0.03 & $<0.01$ & $<0.01$ \\
\hline
\end{tabular}




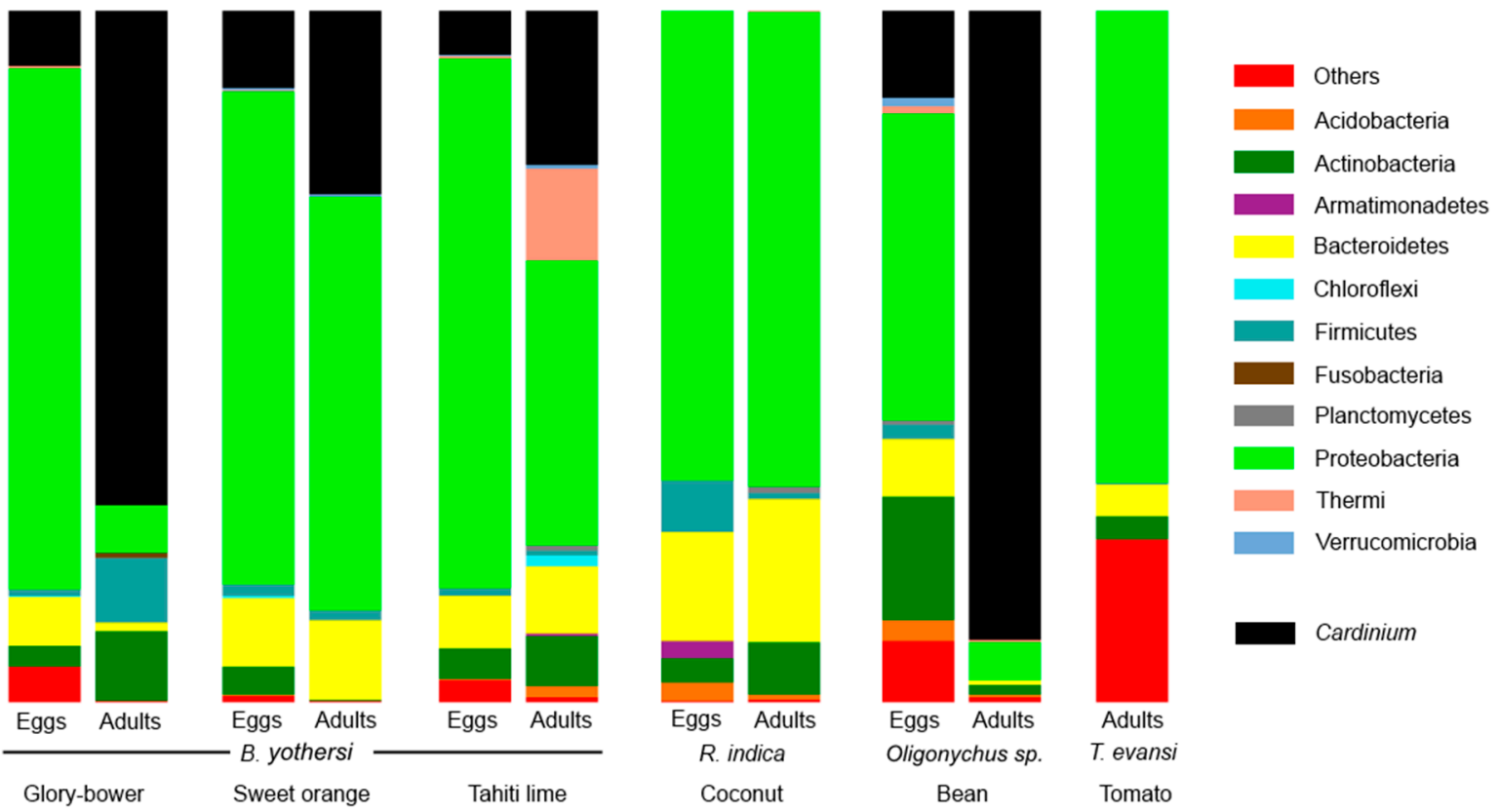

Figure 1. Relative abundance of bacterial phyla found in the mite samples. The proportion of the genus Cardinium is shown in black. Singletons were removed from this and subsequent analyses.

As suggested by the Chao1 index, endosymbionts in adult Oligonychus sp. from beans were the least species-rich sample (Chao1 $=11.2)$, and adult $B$. yothersi from $C$. aurantifolia $($ Chao1 $=45.6)$ were the most species-rich sample (Table 3). Nevertheless, the most diverse bacterial community was obtained from $R$. indica from coconut palms (Shannon $=4.2)$. Overall, B. yothersi richness (Chao1 $=31.5$ ) was higher than that of the other mites $(C h a o 1=28.1)$; however, the $B$. yothersi bacteriome was less diverse (Shannon $=2.4$ ) than that of the other species (Shannon $=3.0$ ). When comparing B. yothersi eggs with their adults, we observed that increase of Cardinium was accompanied by a decrease in the proportion of other OTUs. Specifically, OTUs assigned to Pseudomonadaceae and Burkholderiaceae were proportionally reduced in adults when compared to eggs.

Table 3. Average estimations of bacteria diversity ( \pm standard deviation) based on rarefaction of samples.

\begin{tabular}{ccccc}
\hline Species & Host Plant & Stage & Chao1 & Shannon \\
\hline \multirow{2}{*}{ Brevipalpus yothersi } & Glory-bower & eggs & $100.88 \pm 16.95$ & $3.32 \pm 0.13$ \\
& & adults & $94.75 \pm 16.26$ & $2.79 \pm 0.09$ \\
\cline { 2 - 5 } & \multirow{2}{*}{ Sweet orange } & eggs & $95.20 \pm 11.62$ & $2.73 \pm 0.09$ \\
\cline { 2 - 5 } & \multirow{2}{*}{ Tahiti lime } & adults & $55.93 \pm 9.46$ & $2.12 \pm 0.07$ \\
\hline \multirow{2}{*}{ Raoiella indica } & eggs & $97.66 \pm 18.88$ & $2.36 \pm 0.10$ \\
& \multirow{2}{*}{ Coconut } & adults & $146.02 \pm 21.25$ & $4.24 \pm 0.09$ \\
\hline \multirow{2}{*}{ Oligonychus sp. } & \multirow{2}{*}{ Bean } & adults & $115.49 \pm 15.59$ & $4.74 \pm 0.10$ \\
\hline Tetranychus evansi & Tomato & eggs & $79.46 \pm 7.19$ & $4.42 \pm 0.09$ \\
\hline
\end{tabular}

In general, the bacterial communities containing OTUs assigned to Cardinium were more similar than those lacking the endosymbiont (ANOSIM $R_{\text {BrayCurtis/UniFrac }}=0.84 / 0.59, p<0.05$, Figure 2). Specifically, the bacteriomes of the Oligonychus mite and B. yothersi were more similar among them 
than to those found in the other mite species. Similarity was higher between the less diverse bacterial communities in the eggs of B. yothersi, than to the bacteriomes from their respective adults. As expected, mites where Cardinium was the predominant taxa (adult Oligonychus sp. and adult B. yothersi from C. thomsoniae) were almost identical. The bacteriome of T. evansi adults was more similar to that of $R$. indica than to other bacteriomes in this study.

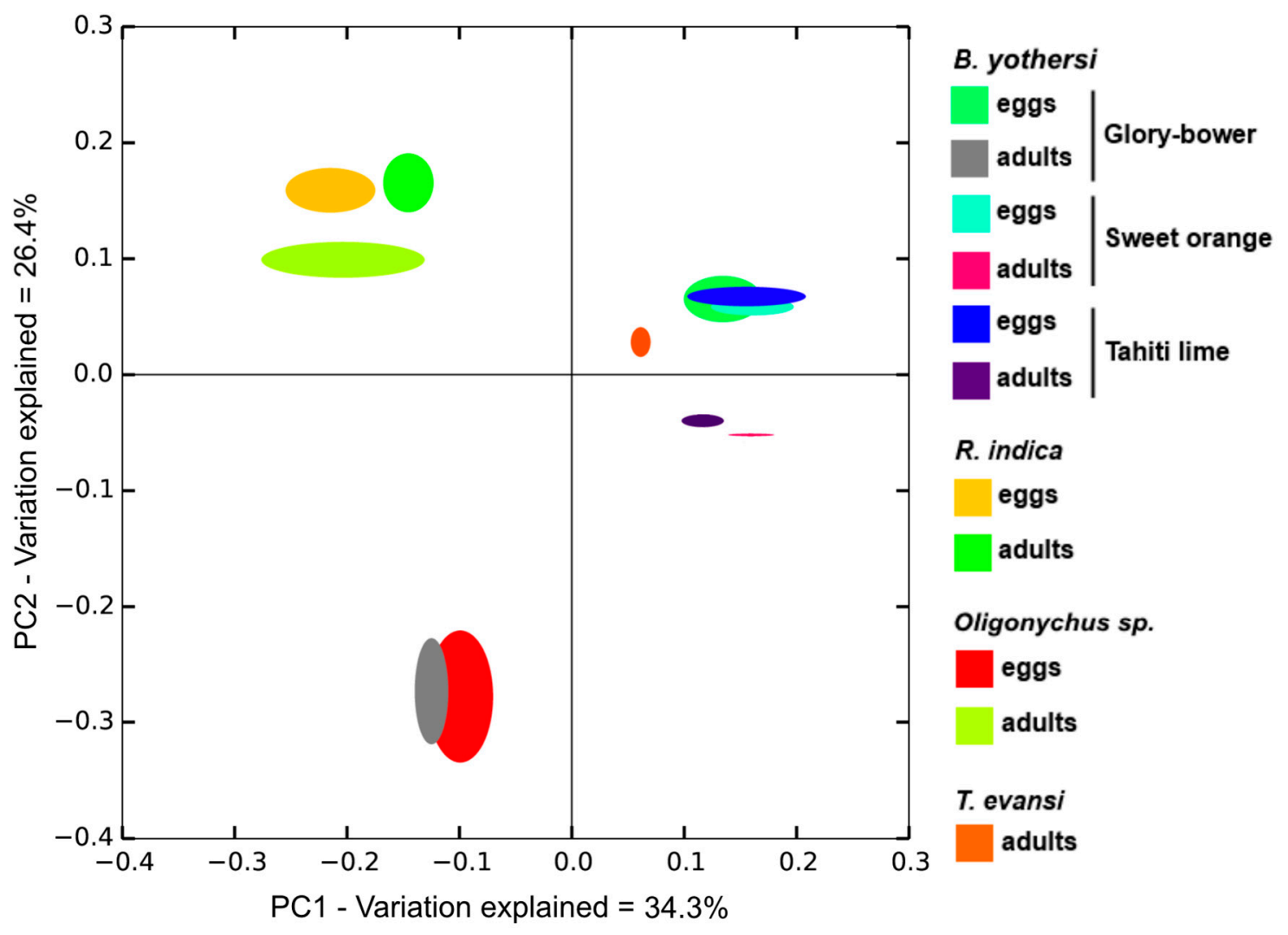

Figure 2. Principal Coordinate Analysis for the dissimilarity among bacterial communities.

\subsection{Analysis of Cardinium Endosymbionts}

The results show that inside each sample of $B$. yothersi, the proportion of OTUs designated as Cardinium is higher in adults than in the eggs (Figure 1). In the sample from C. thomsoniae, Cardinium counts were significantly lower in eggs than in adults $\left(7.9 \%\right.$ vs. $\left.71.5 \%, \chi^{2}=2600.3, p<0.001\right)$. For the sample obtained from $C$. sinensis, we obtained the same pattern $\left(11.1 \%\right.$ vs. $\left.26.5 \%, \chi^{2}=322.5, p<0.001\right)$, as well for the mites collected originally on C. aurantifolia $\left(6.4 \%\right.$ vs. $\left.22.2 \%, \chi^{2}=3164.8, p<0.001\right)$. A significant increase in the amount of counts of Cardinium sequences were also observed in Oligonychus mites obtained from beans. Specifically, Oligonychus sp. eggs had $12.6 \%$ Cardinium sequences whereas the adults had $90.9 \%\left(\chi^{2}=546.4, p<0.001\right)$.

Our phylogenetic analysis of the sequences from Cardinium isolated from different hosts showed that bacteria from Hemiptera, Hymenoptera, and mites form a monophyletic clade. Inside this clade, two main groups can be recognized. One of these groups is dominated by Cardinium endosymbionts originating from Hemiptera (whiteflies and scale insects) and some Hymenoptera. The second group contains all the Cardinium sequences from this study and isolates from other mites and armored scale insects (Diaspididae: Hemiptera). Cardinium from copepods and mosquitoes were placed external to the monophyletic clade, suggesting that these arthropods harbor highly differentiated lineages of these bacteria (Figure 3, Supplementary Materials: Figure S1, Table S2). 


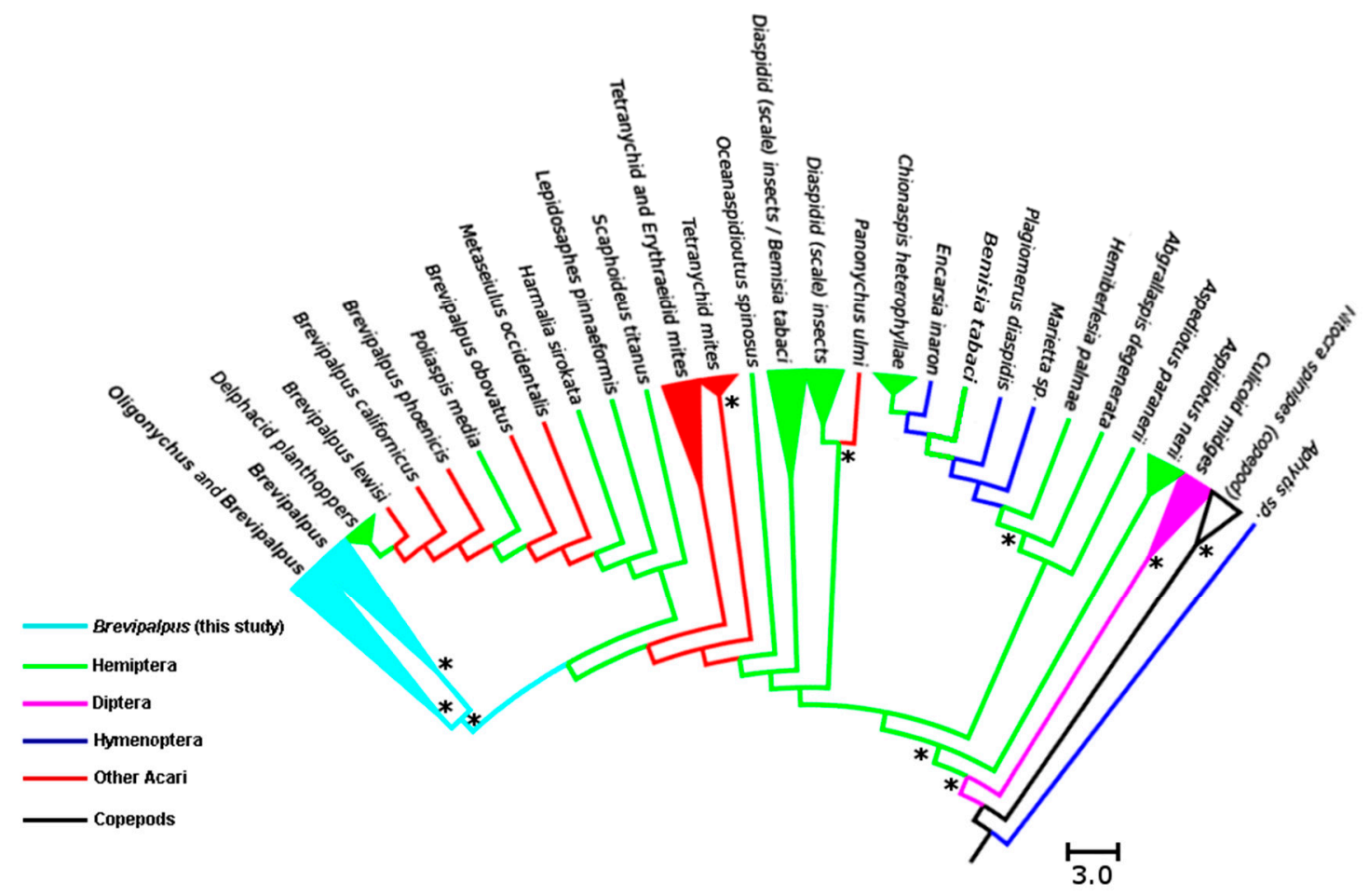

Figure 3. Maximum Parsimony tree for a representative sample of Cardinium (microphotograph credit: E.W. Kitajima) sequences from different arthropods available at GenBank, and sequences obtained in this study. Color legend indicates the host from where the Cardinium was isolated and sequenced. Asterisks show nodes with support higher than $50 \%$ based on bootstrap resampling (1000 replicates).

\section{Discussion}

\subsection{Factors Affecting Diversity in Bacterial Communities}

The low number of taxa present in the bacterial communities of the mites in this study is concordant with other studies on arthropod bacteriomes [35,36]. Our results support the idea of a "core bacteriome" on animals [37], represented by Proteobacteria, Bacteroidetes, and Actinobateria. The low diversity in arthropod microbiomes, if not an artifact of the analyses, could be attributed to the response from the innate immune system in the hosts [37,38]. In contrast to other animals, the less adaptable immune system in invertebrates would allow only a select combination of bacterial taxa. Even though the immune system may be playing a capital role in shaping the diversity of arthropod microbiomes, there are additional possibilities that we will discuss here.

The fact that bacteriome alpha diversity of these mites is reduced in adults in comparison to eggs reflects the existence of mechanisms that are yet to be described, which are involved in the definition of bacterial assemblages. An increasing number of papers report that competition can be an important driver of reduction of diversity in microbial communities [39-42]. Most of the studies on arthropod gut microbiomes show that competition may even lead to exclusion of taxa by several mechanisms such as the depletion of nutrients [43] and $\mathrm{pH}$ changes [44].

In many cases, such as in these mites, the endosymbiont Cardinium increases its relative abundance in the bacterial community possibly by means of competitive exclusion. This would result in a decrease of bacteriome diversity and species richness as has been seen in ticks and fleas [45,46]. However, the host may also shape the bacterial community by generating the conditions for certain bacterial taxa to dominate, a situation known as habitat filtering [47]. In several systems, the dominant endosymbiont confers an advantage in fitness, feeding, or survival to the host $[17,24,48]$. These advantages conferred by the endosymbiont may evoke responses in the host that ultimately favor their proliferation 
throughout the life of the host. As our results show, the endosymbiont Cardinium was significantly more abundant in adults of B. yothersi and Oligonychus sp. than in their respective eggs. Similarly, Sphingomonas sp. (known endosymbiont in non-arthropod systems [49]) was detected at higher proportions in adults than in eggs of $R$. indica. We were not able to obtain samples from T. evansi eggs, but we suspect that Erwinia sp. [50] would also be more abundant in the eggs of T. evansi than in the adults.

Environmental factors can also influence the composition of microbial communities. The mites in this study come from different hosts and locations that represent the founding bacterial populations. Although Cardinium was abundantly present in the three B. yothersi colonies, the proportion of Cardinium varied among them. The colony from Glory-bower showed a dominance of Cardinium over other bacterial taxa, which makes this bacterial community more similar to that found in Oligonychus sp. In fleas and ticks that feed on mammals, it has been shown that microbial communities are affected mostly by environmental factors external to the mammal and by mechanisms dictated by the arthropod itself [46,51]. The results in this study are in agreement with the idea that different mite species may converge to have similar bacterial community profiles, and conspecific mites originating from different plant hosts may show different bacterial assemblages.

In this sense, habitat filtering (i.e., original host-plant selection) may be a strong driving force in shaping the bacteriomes of the mites in this study, possibly leading to specialization in the function of these bacterial communities. This filter imposed by the habitat can be seen as the range of conditions and resources that the mite host offers [52]. The host "selects" only a fraction of all the initial diversity, possibly depending upon its physiological requirements. It would also be expected that habitat filtering results in the components of the bacteriome being more phylogenetically related due to host requirements or inability of the symbiont to adapt to different conditions [53-55]. In the mites from this study, most of the bacterial species belong to either Bacteroidetes (such as Cardinium) or Proteobacteria, which indicates a higher degree of phylogenetic relatedness than would be observed in other communities with lower selective pressures. Nevertheless, this work only represents a snapshot of the existing conditions and under natural, non-controlled habitats, different degrees of competition and habitat filtering may occur depending upon the assessed spatial and temporal scale [56].

\subsection{Phylogenetic Relationship among Cardinium Strains in Different Systems}

The phylogenetic analysis of Cardinium strains failed to show convincing evidence that supports phylogenetic correlation between the evolution of these bacteria and their hosts. Previous works on the distribution of Cardinium indicated that physiological specialization is noticeable due to phylogenetic clustering of Cardinium strains from closely related hosts [57]. Although this idea is not clearly observed in our results, it is possible to infer that Cardinium strains show greater phylogenetic relatedness with the Cardinium strains present in other mites than to hemipterans and hymenopterans. Additionally, Cardinium from copepods and mosquitoes represent highly differentiated lineages from those found in other insects and mites. Although we could not show strong evidence for the idea of the phylogenetic clustering of Cardinium and their hosts, our analysis provides evidence about potential horizontal transmission as an important process in the evolution of Cardinium and their hosts.

\section{Conclusions}

This study represents the first time that the Next Generation Sequencing approach was used on microbial communities of the agriculturally important Tetranychoidea mites [58]. Our results suggest that the bacteriomes of these mites are relatively low in diversity, as in many other arthropods, although diversity was higher in eggs than in adults. The differences between colonies of $B$. yothersi and similarities among species in regards to the composition of the bacterial assemblages shows that the hosts may be differentially filtering the taxa in their bacteriomes. However, we recognize that competition among bacterial species could also contribute to changes in diversity at different degrees depending upon the assessed temporal and spatial scale. The phylogenetic history of Cardinium 
seems to be driven by physiological specialization of the host and horizontal transmission acting at different degrees. It seems implausible that the asexuality associated with Cardinium in arthropods represents an evolutionary dead end $[59,60]$ on the basis that divergence is still extensive at least for the endosymbiont. Understanding the bacteriome associated with the unique biological system represented by $B$. yothersi and other Tetranychoidea is certainly an important step towards enhancing knowledge about the evolution of its asexuality, and might further help to develop strategies for its pest management.

Supplementary Materials: The following are available online at www.mdpi.com/2075-4450/7/4/80/s1. Figure S1: Detailed Maximum Parsimony for Cardinium sequences from this study and others, Table S1: OTU table (contains the counts and taxonomic assignation for each OUT in this study), Table S2: Sequences from GenBank published elsewhere that were used in this study for phylogenetic inference in Cardinium.

Acknowledgments: We want to thank the U.S. Department of Agriculture for partial funding of this work (USDA/APHIS 8272-0685 CA). Thanks to Jessica Falero for collecting the initial Brevipalpus populations. Thanks to Jennifer Beard (Queensland Museum) and Ronald Ochoa (USDA-BARC, Beltsville) for sharing the information about the taxonomic status of Brevipalpus mites and comments to improve the manuscript. Thanks to Carl Childers for comments on the original manuscript draft. Thanks to anonymous reviewers for exceptional suggestions to improve the manuscript.

Author Contributions: Jose Rodrigues and Steven Massey conceived and designed the study; Jose Rodrigues prepared the mite colonies and performed data collection; Oscar Ospina and Steven Massey analyzed the data; Oscar Ospina, Jose Rodrigues, and Steven Massey wrote and reviewed the manuscript.

Conflicts of Interest: The authors declare no conflict of interest.

\section{References}

1. Kitajima, E.W.; Rezende, J.A.M.; Rodrigues, J.C.V. Passion fruit green spot virus vectored by Brevipalpus phoenicis (Acari: Tenuipalpidae) on passion fruit in Brazil. Exp. Appl. Acarol. 2003, 30, 225-231. [CrossRef] [PubMed]

2. Kitajima, E.W.; Rodrigues, J.C.V.; Freitas-Astua, J. An annotated list of ornamentals naturally found infected by Brevipalpus mite-transmitted viruses. Sci. Agric. 2010, 67, 348-371. [CrossRef]

3. Rodrigues, J.C.V.; Childers, C.C. Brevipalpus mites (Acari: Tenuipalpidae): Vectors of invasive, non-systemic cytoplasmic and nuclear viruses in plants. Exp. Appl. Acarol. 2013, 59, 165-175. [CrossRef] [PubMed]

4. Beard, J.J.; Ochoa, R.; Bauchan, G.R.; Trice, M.D.; Redford, A.J.; Walters, T.W.; Mitter, C. Flat Mites of the World. Available online: http://idtools.org/id/mites/flatmites/ (accessed on 8 September 2016).

5. Beard, J.J.; Ochoa, R.; Braswell, W.E.; Bauchan, G.R. Brevipalpus phoenicis (Geijskes) species complex (Acari: Tenuipalpidae)—A closer look. Zootaxa 2015, 3944, 1-67. [CrossRef] [PubMed]

6. Rodrigues, J.C.V.; Kitajima, E.W.; Childers, C.C.; Chagas, C.M. Citrus leprosis virus vectored by Brevipalpus phoenicis (Acari: Tenuipalpidae) on citrus in Brazil. Exp. Appl. Acarol. 2003, 30, 161-179. [CrossRef] [PubMed]

7. Carstens, E.B. Ratification vote on taxonomic proposals to the International Committee on Taxonomy of Viruses (2009). Arch. Virol. 2010, 155, 133-146. [CrossRef] [PubMed]

8. Weeks, A.R.; Marec, F.; Breeuwer, J.A.J. A mite species that consists entirely of haploid females. Science 2001, 292, 2479-2482. [CrossRef] [PubMed]

9. Zchori-Fein, E.; Gottlieb, Y.; Kelly, S.E.; Brown, J.K.; Wilson, J.M.; Karr, T.L.; Hunter, M.S. A newly discovered bacterium associated with parthenogenesis and a change in host selection behavior in parasitoid wasps. Proc. Natl. Acad. Sci. USA 2001, 98, 12555-12560. [CrossRef] [PubMed]

10. Feldhaar, H.; Straka, J.; Krischke, M.; Berthold, K.; Stoll, S.; Mueller, M.J.; Gross, R. Nutritional upgrading for omnivorous carpenter ants by the endosymbiont Blochmannia. BMC Biol. 2007. [CrossRef] [PubMed]

11. Sabree, Z.L.; Kambhampati, S.; Moran, N.A. Nitrogen recycling and nutritional provisioning by Blattabacterium, the cockroach endosymbiont. Proc. Natl. Acad. Sci. USA 2009, 106, 19521-19526. [CrossRef] [PubMed]

12. Oliver, K.M.; Moran, N.A.; Hunter, M.S. Variation in resistance to parasitism in aphids is due to symbiosis not host genotype. Proc. Natl. Acad. Sci. USA 2005, 102, 12795-12800. [CrossRef] [PubMed]

13. Scarborough, C.L.; Ferrari, J.; Godfray, H.C.J. Aphid protected from pathogen by endosymbiont. Science 2005. [CrossRef] [PubMed] 
14. Stouthamer, R.; Breeuwer, J.A.J.; Hurst, G.D. Wolbachia pipientis: Microbial manipulator of arthropod reproduction. Annu. Rev. Microbiol. 1999, 53, 71-102. [CrossRef] [PubMed]

15. Pais, R.; Lohs, C.; Wu, Y.; Wang, J.; Aksoy, S. The obligate mutualist Wigglesworthia glossinidia influences reproduction, digestion, and immunity processes of its host, the tsetse fly. Appl. Environ. Microbiol. 2008, 74, 5965-5974. [CrossRef] [PubMed]

16. Werren, J.H.; Baldo, L.; Clark, M.E. Wolbachia: Master manipulators of invertebrate biology. Nat. Rev. 2008, 6, 741-751. [CrossRef] [PubMed]

17. Oliver, K.M.; Degnan, P.H.; Burke, G.R.; Moran, N.A. Facultative symbionts in aphids and the horizontal transfer of ecologically important traits. Annu. Rev. Entomol. 2010, 55, 247-266. [CrossRef] [PubMed]

18. Cordaux, R.; Bouchon, D.; Greve, P. The impact of endosymbionts on the evolution of host sex-determination mechanisms. Trends Genet. 2011, 27, 332-341. [CrossRef] [PubMed]

19. Lombardo, M.P. Mutualistic endosymbiotic microbes: An underappreciated benefit of group living. Behav. Ecol. Sociobiol. 2008, 62, 479-497. [CrossRef]

20. Wang, Y.; Gilbreath, T.M.; Kukutla, P.; Yan, G.; Xu, J. Dynamic gut microbiome across life history of the malaria mosquito Anopheles gambiae in Kenya. PLoS ONE 2011, 6, e24767. [CrossRef] [PubMed]

21. Vasanthakumar, A.; Handelsman, J.; Schloss, P.D.; Bauer, L.S.; Raffa, K.F. Gut microbiota of an invasive subcortical beetle, Agrilus planipennis Fairmaire, across various life stages. Environ. Entomol. 2008, 37, 1344-1353. [CrossRef]

22. Yen, J.H.; Barr, A.R. New hypothesis of the cause of cytoplasmic incompatibility in Culex pipiens L. Nature 1971, 232, 657-658. [CrossRef] [PubMed]

23. Morse, S.F.; Bush, S.E.; Patterson, B.D.; Dick, C.W.; Gruwell, M.E.; Dittmar, K. Evolution, multiple acquisition, and localization of endosymbionts in bat flies (Diptera: Hippoboscoidea: Streblidae and Nycteribiidae). Appl. Environ. Microbiol. 2013, 79, 2952-2961. [CrossRef] [PubMed]

24. Wang, J.J.; Dong, P.; Xiao, L.S.; Dou, W. Effects of removal of Cardinium infection on fitness of the stored-product pest Liposcelis bostrychophila (Psocoptera: Liposcelididae). J. Econ. Entomol. 2008, 101, 1711-1717. [CrossRef]

25. Rodrigues, J.C.V.; Gallo-Meagher, M.; Ochoa, R.; Childers, C.C.; Adams, B.J. Mitochondrial DNA and RAPD polymorphisms in the haploid mite Brevipalpus phoenicis (Acari: Tenuipalpidae). Exp. Appl. Acarol. 2004, 34, 275-290. [CrossRef] [PubMed]

26. Navajas, M.; Lagnel, J.; Gutierrez, J.; Boursot, P. Species-wide homogeneity of nuclear ribosomal ITS2 sequences in the spider mite Tetranychus urticae contrasts with extensive mitochondrial COI polymorphism. Heredity 1998, 80, 742-752. [CrossRef] [PubMed]

27. Hori, M.; Fukano, H.; Suzuki, Y. Uniform amplification of multiple DNAs by emulsion PCR. Biochem. Biophys. Res. Commun. 2007, 352, 323-328. [CrossRef] [PubMed]

28. Caporaso, J.G.; Kuczynski, J.; Stombaugh, J.; Bittinger, K.; Bushman, F.D.; Costello, E.K.; Fierer, N.; Peña, A.G.; Goodrich, J.K.; Gordon, J.I.; et al. QIIME allows analysis of high-throughput community sequencing data. Nat. Methods 2010, 7, 335-336. [CrossRef] [PubMed]

29. Caporaso, J.G.; Bittinger, K.; Bushman, F.D.; Desantis, T.Z.; Andersen, G.L.; Knight, R. PyNAST: A flexible tool for aligning sequences to a template alignment. Bioinformatics 2010, 26, 266-267. [CrossRef] [PubMed]

30. Wang, Q.; Garrity, G.M.; Tiedje, J.M.; Cole, J.R. Naive bayesian classifier for rapid assignment of rRNA sequences into the new bacterial taxonomy. Appl. Environ. Microbiol. 2007, 73, 5261-5267. [CrossRef] [PubMed]

31. Tamura, K.; Stecher, G.; Peterson, D.; Filipski, A.; Kumar, S. MEGA6: Molecular Evolutionary Genetics Analysis version 6.0. Mol. Biol. Evol. 2013, 30, 2725-2729. [CrossRef] [PubMed]

32. Baumann, P. Biology of bacteriocyte-associated endosymbionts of plant sap-sucking insects. Annu. Rev. Microbiol. 2005, 59, 155-189. [CrossRef] [PubMed]

33. Moran, N.A.; McCutcheon, J.P.; Nakabachi, A. Genomics and evolution of heritable bacterial symbionts. Annu. Rev. Genet. 2008, 42, 165-190. [CrossRef] [PubMed]

34. Mcneill, M.R.; Richards, N.K.; White, J.A.; Laugraud, A. Hidden arsenal: Endosymbionts in arthropods, their role and possible implications for biological control success. N. Z. Plant Prot. 2014, 67, 204-212.

35. Moran, N.A.; Hansen, A.K.; Powell, J.E.; Sabree, Z.L. Distinctive gut microbiota of honey bees assessed using deep sampling from individual worker bees. PLoS ONE 2012, 7, e36393. [CrossRef] [PubMed] 
36. Osei-Poku, J.; Mbogo, C.M.; Palmer, W.J.; Jiggins, F.M. Deep sequencing reveals extensive variation in the gut microbiota of wild mosquitoes from Kenya. Mol. Ecol. 2012, 21, 5138-5150. [CrossRef] [PubMed]

37. Jones, R.T.; Sanchez, L.G.; Fierer, N. A cross-taxon analysis of insect-associated bacterial diversity. PLoS ONE 2013, 8, e61218. [CrossRef] [PubMed]

38. Pernice, M.; Simpson, S.J.; Ponton, F. Towards an integrated understanding of gut microbiota using insects as model systems. J. Insect Physiol. 2014, 69, 12-18. [CrossRef] [PubMed]

39. Juchault, P.; Rigaud, T.; Mocquard, J.-P. Evolution of sex-determining mechanisms in a wild population of Armadillidium vulgare Latr. (Crustacea, Isopoda): Competition between two feminizing parasitic sex factors. Heredity 1992, 69, 382-390. [CrossRef]

40. Macaluso, K.R.; Sonenshine, D.E.; Ceraul, S.M.; Azad, A.F. Rickettsial infection in Dermacentor variabilis (Acari: Ixodidae) inhibits transovarial transmission of a second Rickettsia. J. Med. Entomol. 2002, 39, 809-813. [CrossRef] [PubMed]

41. Kondo, N.; Shimada, M.; Fukatsu, T. Infection density of Wolbachia endosymbiont affected by co-infection and host genotype. Biol. Lett. 2005, 1, 488-491. [CrossRef] [PubMed]

42. Hughes, G.L.; Dodson, B.L.; Johnson, R.M.; Murdock, C.C.; Tsujimoto, H.; Suzuki, Y.; Patt, A.A.; Cui, L.; Nossa, C.W.; Barry, R.M.; et al. Native microbiome impedes vertical transmission of Wolbachia in Anopheles mosquitoes. Proc. Natl. Acad. Sci. USA 2014, 111, 12498-12503. [CrossRef] [PubMed]

43. Indiragandhi, P.; Anandham, R.; Madhaiyan, M.; Kim, G.H.; Sa, T. Cross-utilization and expression of outer membrane receptor proteins for siderophore uptake by Diamondback moth Plutella xylostella (Lepidoptera: Plutellidae) gut bacteria. FEMS Microbiol. Lett. 2008, 289, 27-33. [CrossRef] [PubMed]

44. Broderick, N.A.; Raffa, K.F.; Goodman, R.M.; Handelsman, J. Census of the bacterial community of the gypsy moth larval midgut by using culturing and culture-independent methods. Appl. Environ. Microbiol. 2004, 70, 293-300. [CrossRef] [PubMed]

45. Pornwiroon, W.; Kearney, M.T.; Husseneder, C.; Foil, L.D.; Macaluso, K.R. Comparative microbiota of Rickettsia felis-uninfected and -infected colonized cat fleas, Ctenocephalides felis. ISME J. 2007, 1, $394-402$. [CrossRef] [PubMed]

46. Hawlena, H.; Rynkiewicz, E.; Toh, E.; Alfred, A.; Durden, L.A.; Hastriter, M.W.; Nelson, D.E.; Rong, R.; Munro, D.; Dong, Q.; et al. The arthropod, but not the vertebrate host or its environment, dictates bacterial community composition of fleas and ticks. ISME J. 2013, 7, 221-223. [CrossRef] [PubMed]

47. Levy, R.; Borenstein, E. Metabolic modeling of species interaction in the human microbiome elucidates community-level assembly rules. Proc. Natl. Acad. Sci. USA 2013, 110, 12804-12809. [CrossRef] [PubMed]

48. Zindel, R.; Gottlieb, Y.; Aebi, A. Arthropod symbioses: A neglected parameter in pest- and disease-control programmes. J. Appl. Ecol. 2011, 48, 864-872. [CrossRef]

49. Lee, J.; Shin, S.C.; Kim, S.J.; Kim, B.K.; Hong, S.G.; Kim, E.H.; Park, H.; Lee, H. Draft genome sequence of a Sphingomonas sp., an endosymbiotic bacterium isolated from an arctic lichen Umbilicaria sp. J. Bacteriol. 2012, 194, 3010-3011. [CrossRef] [PubMed]

50. Estes, A.M.; Hearn, D.J.; Bronstein, J.L.; Pierson, E.A. The olive fly endosymbiont, "Candidatus Erwinia dacicola", switches from an intracellular existence to an extracellular existence during host insect development. Appl. Environ. Microbiol. 2009, 75, 7097-7106. [CrossRef] [PubMed]

51. Jones, R.T.; Knight, R.; Martin, A.P. Bacterial communities of disease vectors sampled across time, space, and species. ISME J. 2010, 4, 223-231. [CrossRef] [PubMed]

52. Costello, E.K.; Stagaman, K.; Dethlefsen, L.; Bohannan, B.J.M.; Relman, D.A. The application of ecological theory toward an understanding of the human microbiome. Science 2012, 336, 1255-1262. [CrossRef] [PubMed]

53. Horner-Devine, M.C.; Bohannan, B.J.M. Phylogenetic clustering and overdispersion in bacterial communities. Ecology 2006, 87, S100-S108. [CrossRef]

54. Ceja-Navarro, J.A.; Nguyen, N.H.; Karaoz, U.; Gross, S.R.; Herman, D.J.; Andersen, G.L.; Bruns, T.D.; Pett-Ridge, J.; Blackwell, M.; Brodie, E.L. Compartmentalized microbial composition, oxygen gradients and nitrogen fixation in the gut of Odontotaenius disjunctus. ISME J. 2014, 8, 6-18. [CrossRef] [PubMed]

55. Koeppel, A.F.; $\mathrm{Wu}, \mathrm{M}$. Species matter: The role of competition in the assembly of congeneric bacteria. ISME J. 2014, 8, 531-540. [CrossRef] [PubMed]

56. Emerson, B.C.; Gillespie, R.G. Phylogenetic analysis of community assembly and structure over space and time. Trends Ecol. Evol. 2008, 23, 619-630. [CrossRef] [PubMed] 
57. Zchori-Fein, E.; Perlman, S.J. Distribution of the bacterial symbiont Cardinium in arthropods. Mol. Ecol. 2004, 13, 2009-2016. [CrossRef] [PubMed]

58. Chaisiri, K.; McGarry, J.W.; Morand, S.; Makepeace, B.L. Symbiosis in an overlooked microcosm: A systematic review of the bacterial flora of mites. Parasitology 2015, 142, 1152-1162. [CrossRef] [PubMed]

59. Maynard-Smith, J. The Evolution of Sex; Cambridge University Press: Cambridge, UK, 1978.

60. Lynch, M.; Burger, R.; Butcher, D.; Gabriel, W. The mutational meltdown in asexual populations. J. Hered. 1993, 84, 339-344. [PubMed]

(C) 2016 by the authors; licensee MDPI, Basel, Switzerland. This article is an open access article distributed under the terms and conditions of the Creative Commons Attribution (CC-BY) license (http://creativecommons.org/licenses/by/4.0/). 